\title{
Akad Musyarakah Mutanaqisa: Inovasi Baru Produk Pembiayaan Bank Syariah
}

\author{
Putri Dona Balgis ${ }^{1}$ \\ Universitas Padjajaran, Jln. Dipatiukur No. 35 Bandung \\ Email:putridonabalgis@gmail.com
}

\begin{abstract}
Product based partnersip with profit-loss sharing like Musyarakah as a competitive product in Islamic Banking has not showed significant growth like another products. One of derivative contract of musyarakah which is potentially practiced as an innovation product in Islamic banking is musyarakah mutanaqisa contract. This study decribes about musyarakah mutanaqisa contract, the difference between musyarakah mutanaqisa and conventional lease, the treatment of accounting, and the practice of musyarakah mutanaqisa in Indonesia. In Indonesia, four of thirteen Islamic Banks in Indonesia offer a financing product with musyarakah mutanaqisa contract. They are Bank Muamalat, Maybank Syariah, Panin Bank Syariah, and Bank Mega Syariah.
\end{abstract}

Keyword: musyarakah mutanaqisa contract, financing product, Islamic Bank

\begin{abstract}
Abstrak
Produk perbankan Syariah berbasis kemitraan dengan "profit-loss sharing" seperti Musyarakah tidak telah menunjukkan pertumbuhan yang signifikan seperti produk lain. Salah satu kontrak derivatif musyarakah yang berpotensi dipraktekkan sebagai produk inovasi dalam perbankan Islam adalah kontrak musyarakah mutanaqisa. Studi ini meneliti tentang perbedaan antara musyarakah mutanaqisa dan sewa konvensional, pencatatan akuntansi dan praktek musyarakah mutanaqisa di Indonesia. Di Indonesia, empat dari tiga belas Bank Syariah menawarkan produk pembiayaan dengan musyarakah mutanaqisa kontrak. Bank Syariah di Indonesia menawarkan produk pembiayaan dengan musyarakah mutanaqisa kontrak.adalah Bank Muamalat, Maybank Syariah, Panin Bank Syariah, dan Bank Mega Syariah.
\end{abstract}

Kata kunci: kontrak musyarakah mutanaqisa, financing product, bank syariah

\section{PENDAHULUAN}

\section{Latar Belakang}

Animo masyarakat terhadap perbankan syariah mengalami peningkatan, hal ini tampak dari bertambahnya segmen dan jumlah nasabah. Seiring meningkatnya animo masyarakat akan perankan syariah, maka hal ini mendorong perbankan syariah untuk terus melakukan pengembangan dan inovasi produk yang ditawarkan agar mampu semakin menarik minat masyarakat, serta mampu menjawab kebutuhan masyarakat saat ini. Disamping itu, perbankan syariah harus memastikan bahwa produk yang ditawarkan telah sesuai dengan prinsip syariah, karena inilah hal pokok yang membedakan bank syariah dan bank konvensional.

Produk berbasis kemitraan dengan bagi hasil seperti Musyarakah sebagai produk unggulan kompetitif perbankan syariah belum mengalami pertumbuhan sebagaimana produk lainnya. Kurangnya pengembangan produk berbasis kemitraan diperbankan syariah yang lebih fleksibel jangka waktunya, terutama pembiayaan jangka panjang menyebabkan perbankan syariah lebih banyak produknya didasari oleh pembiayaan dengan pendapatan tetap yang memiliki kemiripan dengan pola konvensional yang menggunakan struktur

${ }^{1}$ Nomor telepon: 085375354707 
pendapatan yang tetap (fixed income) dan cenderung berjangka waktu pendek dan menengah. Perlu ada inovasi yang mampu mendorong bank syariah untuk keluar dari dominasi akad murabahah. Awal tahun per Januari 2015 total pembiayaan akad murabahah mencapai 58,78\%.

Pembiayaan kepemilikan rumah dan kendaraan yang merupakan salah satu pembiayaan favorit pada Bank Syariah Indonesia, saat ini menggunakan akad murabahah. Akad musyarakah mutanaqisa bisa menjadi alternative untuk diterapkan pada produk pembiayaan kepemilikan rumah dan kendaraan. Mengingat kebutuhan akan kepemilikan rumah dan kendaraan memang kebutuhan dasar semua masyrakat, sehingga pangsa pasatnya luas. Pada Bank Muamalat Lumajang, KPR Muamalat iB dengan akad musyarakah mutanaqisa sangat diminati oleh masyarakat Lumajang dengan persentase $56 \%$ dari seluruh produk pembiayaan. Lebih tinggi dari produk pembiayaan murabahah yang persentasenya 34\%. (Putri Kamilatur, 2015)

Ahli Syariah sepakat pada proses implementasi Musyarakah Mutanaqisa. Bendjilali dan Khan (1995) dan Taqi Usmani (2002) sebagai contoh sepakat bahwa Musyarakah Mutanaqisa dapat membantu masyarakat untuktidak terlalu mengandalkan fasilitas pembiayaan lainnya seperti Ba'I Bitamin Ajil, Murabahah dan lain-lain. Ahli syariah juga sepakat bahwa Musyarakah Mutanaqisa adalah implementasi terbaik untuk pembiayaan kepemilikan rumah atau mesin dimana kedua aset ini dapat disewakan sesuai kesepakatan sewa. Kepemilkan bersama atas rumah atau aset diperbolehkan oleh semua sekolah fiqh karena pemberi pembiayaan menjual porsinya kepada nasabah atau klien. (Taqi Usmani, 2002)

Penerapan akad musyarakah mutanaqisa merupakan keniscayaan yang tidak bisa ditawar-tawar lagi. Hal ini disebabkan karena penggunaan akad murabahah untuk pembiayaan KPR Syariah bertenor panjang (di atas 4 tahun) pastilah tidak cocok dan tidak tepat. Penggunaan akad murabahah akan membuat pricing (harga) KPRS akan menjadi lebih mahal dibanding konvensional, karena harga jual murabahah bersifat fix, sementara harga pasar fluktuatif. Untuk mengatasi risiko fluktuasi cost of fund, terpaksa bank syariah menaikkan harga (margin) murabahah. Lebih mahalnya harga murabahah ini akan mempengaruhi citra yang kurang baik bagi bank-bank syariah. Sebab bank syariah dicitrakan bank yang mahal. Akad yg seharusnya diterapkan adalah musyarakah mutanaqishah (MMq) yang memiliki banyak keunggulan. Selain harga bisa bersaing, DP nya juga lebih rendah dari KPR konvensional yakni hanya $15 \%$. Ketentuan ini akan membuat produk KPR Syariah lebih unggul dibanding konvensional dan tentunya akan semakin lebih diminati. (iqtishadconsulting.com, 2015)

Hal ini dapat menjadi acuan ataupun semangat bagi bank syariah lainnya untuk menerapkan akad musyarakah mutanaqisa khususnya pada produkpembiayaan kepemilikan rumah dan kendaraan. Dengn akad ini, bank juga mendapatkan keuntungan karena dapat meningkatkan jumlah portofolio pembiayaan consumer, sehingga dana funding dan lending menjadi seimbang. Selain bermanfaat kepada Bank juga bermanfaat bagi nasabah karena dapat memiliki rumah sebagai tempat hunian sekaligus peningkatan aset dan dapat membayar angsuran secara pasti sesuai prinsip syariah. (Putri Kamilatur, 2015)

Oleh karena itu, pengembangan produk bank syariah dengan akad musyarakah mutanaqisa perlu didorong. Pengetahuan dan pemahaman masyarakat mengenai akad yang terkategori masih asing ini perlu lebih diperhatikan kembali. Melalui berbaga acara seerti seminar, talkshow atauun sosialisasi bahkan dengan cara menulis atikelseperti ini bisa menjadi sarana penyampaian pengetahuan dan pemahaman kepada masyarakat. Sehingga penulis berpikir untuk mendeskripsikan mengenai akad musyarakah mutanaqisa ini.

\section{Rumusan Masalah}

Berdasarkan latar belakang di atas, yang menjadi rumusan masalah dalam artikel ini adalah "apa yang dimaksud dengan akad musyarakah mutanaqisa serta perbedaannya dengan conventional lease?", "bagaimana praktik dan perlakuan akuntansi akad musyarakah mutanaqisa di Indonesia?" 


\section{HASIL DAN PEMBAHASAN}

\section{Musyarakah Mutanaqisa}

Musyarakah Mutanaqishah (MMQ) adalah salah satu produk pengembangan dari produk berbasis akad Musyarakah. Musyarakah Mutanaqishah dapat diaplikasikan sebagai suatu produk pembiayaan perbankan syariah berdasarkan prinsip syirkah 'inan, dimana porsi modal (hishshah) salah satu syarik (mitra) yaitu Bank berkurang disebabkan oleh pembelian atau pengalihan komersial secara bertahap (naqlul hishshah bil 'iwadh mutanaqishah) kepada syarik (mitra) yang lain yaitu Nasabah. (OJK, 2016)

Musyarakah mutanaqishah (diminishing partnership) adalah bentuk kerjasama antara dua pihak atau lebih untuk kepemilikan suatu barang atau asset. Dimana kerjasama ini akan mengurangi hak kepemilikan salah satu pihak sementara pihak yang lain bertambah hak kepemilikannya. Perpindahan kepemilikan ini melalui mekanisme pembayaran atas hak kepemilikan yang lain. Bentuk kerjasama ini berakhir dengan pengalihan hak salah satu pihak kepada pihak lain. Dari definisi pemahaman tersebut, konsep akad musyarakah mutanaqishah dijadikan sebuah konsep dalam pembiayaan perbankan syariah, yaitu kerjasama antara bank syariah dengan nasabah untuk pengadaan atau pembelian suatu barang yang mana asset barang tersebut jadi milik bersama. Adapun besaran kepemilikan dapat ditentukan sesuai dengan sejumlah modal atau dana yang disertakan dalam kontrak kerjasama tersebut. Selanjutnya pihak nasabah akan membayar (mengangsur) sejumlah modal atau dana yang dimiliki oleh bank syariah. Jumlah modal bank syariah semakin lama semakin kecil, berbanding terbalik dengan jumlah modal nasabah yang semakin bertambah karena pembayaran angsuran pada setiap bulan. Pada akhir masa pembiayaan, jumlah modal bank telah diambil alih $100 \%$ oleh nasabah sehingga kepemilikan atas rumah (contoh-pen.) dialihkan menjadi atas nama nasabah. (Putri Kamilatur, 2015)

Perpindahan kepemilikan dari porsi bank syariah kepada nasabah seiring dengan bertambahnya jumlah modal nasabah dari pertambahan angsuran setiap bulannya. Apabila masa angsuran berakhir, berarti kepemilikan suatu barang atau benda tersebut sepenuhnya menjadi milik nasabah. Penurunan porsi kepemilikan bank syariah terhadap barang atau benda berkurang secara proporsional sesuai dengan besarnya angsuran. Selain sejumlah angsuran yang harus dilakukan nasabah untuk mengambil alih kepemilikan, nasabah harus membayar sejumlah sewa kepada bank syariah hingga berakhirnya batas kepemilikan bank syariah.

\section{Transfer ownership of assets}

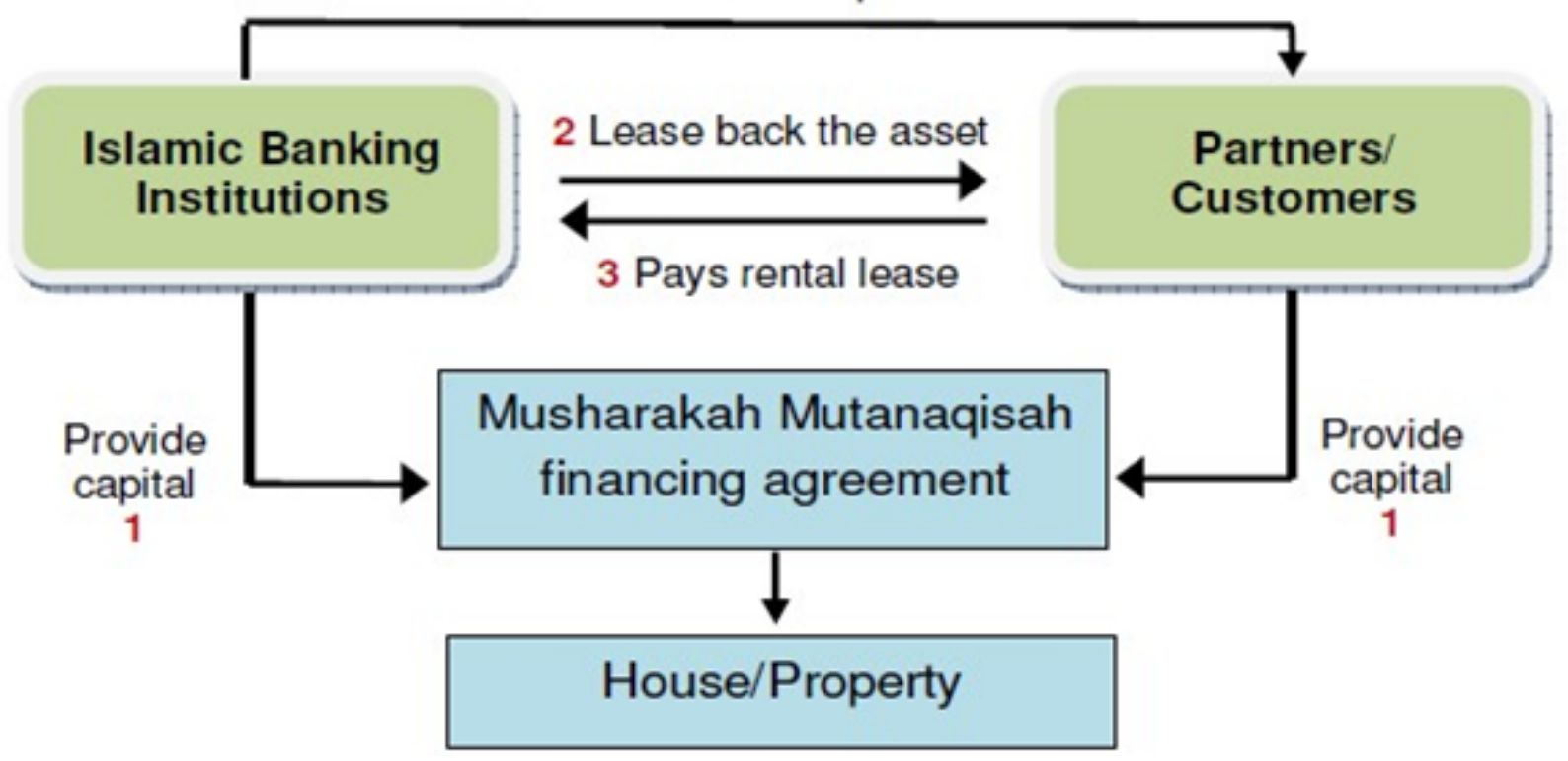

Gambar 1. Skema Alur Transaksi Musyarakah Mutanaqisa (Aris, 2012) 
Pembayaran sewa dilakukan bersamaan dengan pembayaran angsuran. Pembayaran angsuran merupakan bentuk pengambilalihan porsi kepemilikan bank syariah. Sedangkan pembayaran sewa adalah bentuk keuntungan (fee) bagi bank syariah atas kepemilikannya terhadap aset tersebut.Pembayaran sewa sekaligus merupakan bentuk kompensasi kepemilikan dan kompensasi jasa bank syariah.

Musyarakah Mutanaqisah dan perwujudannya pada lembaga keuangan Islam secara global setidaknnya terdapat tujuh jenis: (International Association of Islamic Banks 1982; Islamic Fiqh Academy 2004; al-Imrani 2010; al-Kawamilah 2008 dalam Naim, 2015)

\section{Pembiayaan Modal Kerja}

Dimana karyawan lembaga keuangan Islam menyediakan aset yang ia tidak dapat memanfaatkannya seperti memiliki pabrik dan tidak mampu membiayai bahan untuk produksi, bank akan menjadi mitra dengan jumlah tertentu yang memadai dan membagi porsi keuntungannya dan pembagia dalam partisipasi modal. Kedua pihak setuju bahwa perusahaan menjual bagiannya (porsi) ke mitra dalam pembayaran lump sum atau cicilan dan porsi perusahaan akan berkurang dimana porsi karyawan meningkat sampai semua angsuran dibayar dan semua hak dipindahkan pada karyawan.

\section{Manufaktur}

Dimana karyawan menyediakan tanah dan meminta lembaga keuangan Islam untuk membangun kontrak manufaktur (yang melegitimasi produksi dalam penyelesaian sebagaiakad yang legal). Partner akan membayar sebagian dari dana yang dibutuhkan, jika pemilik tanah menetapkan kepemilikan untuk dirinya sendiri, keuntungan akan dibagi antara mitra berdasarkan rasio yang telah disepakati sebelumnya. Namun, pemilik tanah dalam hal ini akan membayar lembaga keuangan sesuai porsinya terhadap gedung tersebut dengan cara pembayaran lump sum atau angsuran. Lembaga keuangan tidak memiliki hak untuk mengambil hak keuangannya dengan menaikkan biaya atau pembayaran diperlukan. Di mana kepentingan partner adalahmenginvestasikan tanah pada sebuah investasi kemudian akan menjadi mitra dengan lembaga keuangan dalam pembangunan tanah tersebut, dengan demikian, ia berhak untuk setiap kenaikan uang dan pemilik tanah memiliki hak untuk memilih antara jual atau untuk membeli dengan harga pasar.

\section{Musyarakah Mutanaqisah oleh Lembagaan Pembiayaan Kelompok Mitra}

Dimana bank yang terlibat dengan yang lain dalam pembentukan atau pembiayaan proyek. Perjanjian di awal akan penarikan modal dari salah satu pemodal atau lebih untuk mentransfer kepemilikan legal untuk mitra lain atau mitra dan berbagi keuntungan sesuai kesepakatan awal berdasarkan Musyarakah Mutanaqisah.

\section{Musyarakah "al-Muntahiyah bi al-Tamlik" dengan ijarah}

Dimana sebuah kesepakatan dicapai antara lembaga keuangan dan mitra pada proyek konstruksi dengan kesepakatan mitra untuk menyewa gedung selama jangka waktu tertentu dengan membayar sewa, dengan demikian, mitra menjadi penyewa. Pembagian keuntungan akan didasarkan pada rasio yang telah disepakati . Dalam kasus mode ini: bisa dikatakan (lembaga keuangan adalah pemilik dari keseluruhan bangunan): Saya menjual kepada Anda 3/4 bagian saya di gedung ini senilai ... dan jumlah biaya sewa Anda jika 3/4 sewa adalah ... .untuk periode yang berakhir pada 30/12/1424, dan saya akan menjual kepada Anda pada akhir periode pada $3 / 4$ nya senilai ...... dan sisa biaya sewa dari $1 / 3$ nya senilai ...... berakhir pada $30 / 12 / 1425$ dan saya akan menjual kepada Anda pada akhir periode yang telah ditentukan dari jumlah $1 / 3$ yang tersisa dan yang terakhir dari porsi saya dalam proyek ini senilai ...... Pada akhir akad kepemilikan bangunan akan dipindahkan kepada mitra (penyewa) baik fisik dan manfaat.

\section{Musyarakah Mutanaqisah dengan pembiayaan Kemitraan}

Dimana lembaga keuangan dan mitra setuju pada seluruh atau sebagian pembiayaan proyek dengan pengembalian yang pasti dan didasarkan pada kesepakatan dari lembaga keuangan dan mitra tentang porsipenerimaan 
return lembaga sertan hak pengambilan dari porsi yang tersisa dari return/profits atau jumlah lainnya yang disepakati sehingga porsi penarikan institusi akan menutupi pembayaran dari porsi modal.

\section{Musyarakah Mutanaqisah dengan Kemitraan melalui Porsi Kepemilikan}

Ini adalah di mana porsi kepemilikan lembaga keuangan dan mitra dipastikan dalam kemitraan pada porsi yang mewakili total nilai pokok aset kemitraan misalnya-, masingmasing mitra menerima bagian tertentu dari hasil/keuntungan atas realisasi aset. Mitra memiliki hak untuk memperoleh bagian tertentu atas porsi kepemilikannya dimana sebagian porsi kepemilikan bank berkurang secara terus-menerus hingga mitra mengakuisisi seluruhan porsi kepemilikan. Dengan demikian, kepemilikan tunggal aset dipindahkan kepada mitra tanpa cadangan (sisa).

\section{Musyarakah Mutanaqisah melalui Mudharabah}

Dimana lembaga keuangan menyediakan modal untuk suatu proyek tertentu dan mitra meyediakan jasa. Keuntungannya adalah bagi hasil antara mereka dengan kesepakatan dari lembaga keuangan untuk memiliki proyek tersebut melalui skema Musyarakah Mutanaqisah.

\section{Perlakuan Akuntansi Akad Musyarakah Mutanaqisa}

Hingga saat ini belum ada PSAK yang secara detail mengatur tentang Musyarakah Mutanaqisa. Namun PSAK Syariah No. 106 yang mengatur tentang akad musyarakah dapat digunakan sebagai acuan perlakuan akad musyarakah mtanaqisa. Karena tidak dapat dipungkiri bahwa akad musyarakah mutanaqisa merupakan salah satu akad turuan dari akad musyarakah.

\section{Musyarkah Mutanaqisa Vs. Conventional Lease}

Tabel 1. Perbedaan Akad Musyarakah Mutanaqisa dan Conventional Lease

\begin{tabular}{|c|c|c|}
\hline Keterangan & MMQ & Conventional Lease \\
\hline Jenis akad/kontrak & Musyarakah, ijarah kemudian penjualan & Pinjaman plus bunga (dilarang; riba) \\
\hline Kepemilikan & Berdasarkan persentasi kontribusi & $\begin{array}{l}\text { Ditahan atau dimiliki oleh Bank/ } \\
\text { Lembaga leasing }\end{array}$ \\
\hline \multirow[t]{2}{*}{ Risiko } & Bank dan nasabah secara & Nasabah menanggung \\
\hline & $\begin{array}{l}\text { bersama-sama memanggung risiko sesuai } \\
\text { rasio kepemilikannya }\end{array}$ & keselurahan risiko aset \\
\hline $\begin{array}{l}\text { Waktu pembayaran } \\
\text { sewa }\end{array}$ & $\begin{array}{l}\text { Sewa baru dibayarkan saat property telah } \\
\text { memberikan manfaat }\end{array}$ & $\begin{array}{l}\text { Nasabah harus membayar pada awal } \\
\text { kontrak meskipun property masih } \\
\text { dalam konstruksi }\end{array}$ \\
\hline $\begin{array}{l}\text { Perubahan tingkat } \\
\text { sewa }\end{array}$ & $\begin{array}{l}\text { Bisa berubah secara periodik jika disetujui } \\
\text { oeh kedua pihak dikarenakan oleh } \\
\text { perubahan kondisi pasar atau market rate }\end{array}$ & $\begin{array}{l}\text { Bisa berubah berdasarkan fluktuasi } \\
\text { tingkat bunga }\end{array}$ \\
\hline Bagi hasil & $\begin{array}{l}\text { Bank dan nasabah akan membagi } \\
\text { keuntungan berdasarkan rasio yang telah } \\
\text { disepakati (nisbah) }\end{array}$ & $\begin{array}{l}\text { Tidak ada bagi hasil antara bank dan } \\
\text { nasabah }\end{array}$ \\
\hline $\begin{array}{l}\text { Keterlambatan } \\
\text { pembayaran }\end{array}$ & $\begin{array}{l}\text { Dikenakan biaya keterlambatan tidak lebih } \\
\text { dari } 1 \% \text { dan dialokasikan ke dalam dana } \\
\text { kebajikan }\end{array}$ & $\begin{array}{l}\text { Dikenakan biaya penalty kepada } \\
\text { nasabah atas keterlambatan } \\
\text { pembayaran dan bunga akan } \\
\text { ditambahkan }\end{array}$ \\
\hline $\begin{array}{l}\text { Ketidakmampuan } \\
\text { pelunasan oleh } \\
\text { nasabah }\end{array}$ & $\begin{array}{l}\text { Bank akan menjual aset dan membagi hasil } \\
\text { penjualan dan keuntungan penjualan (jika } \\
\text { ada) sesuai persentase kepemilikan saat itu }\end{array}$ & $\begin{array}{l}\text { Bank akan mengakhiri kontrak dan } \\
\text { mengambil alih aset }\end{array}$ \\
\hline Kenaikan biaya aset & $\begin{array}{l}\text { Tidak berdasakan tingkat bunga namun } \\
\text { berdasarkan market price aset }\end{array}$ & Berdasarkan tingkat bunga \\
\hline $\begin{array}{l}\text { Pandangan ahli } \\
\text { syariah }\end{array}$ & Menerima & Melarang \\
\hline
\end{tabular}


Berdasarkan PSAK No. 106 dinyatakan bahwa perlakuan akuntansi untuk musyarakah meliputi pengakuan dan pengukuran, penyajian serta pengungkapan. Pengakuan dan pengukuran investasi musyarakah diakui pada saat penyerahan kas atau aset non kas untuk usaha musyarakah.

Pengukuran investasi musyarakah:

a. Dalam bentuk kas dinilai sebesar jumlah yang diserahkan

b. Dalam bentuk aset nonkas dinilai sebesar nilai wajar dan jika terdapat selisih antara nilai wajar dan nilai buku aset nonkas, maka selisih tersebut diakui sebagai (i) keunggulan tangguhan dan diamortisasi selama masa akad; atau (ii) kerugian pada saat terjadinya.

Mitra pasif menyajikan hal-hal sebagai berikut yang terkait dengan usaha musyarakah dalam laporan keuangan: (i) Kas atau aset nonkas yang diserahkan kepada mitra aktif disajikan sebagai investasi musyarakah; (ii) Keuntungan tangguhan dari selisih penilaian aset nonkas yang diserahkan pada nilai wajar disajikan sebagai pos lawan (contra account) dari investasi musyarakah.

Mitra mengungkapkan hal-hal yang terkait transaksi musyarakah, tetapi tidak terbatas, pada:

a. Isi kesepakatan utama usaha musyarakah, seperti porsi dana, pembagian hasil usaha, aktivitas usaha musyarakah, dan lain-lain;

b. Pengelola usaha, jika tidak ada mitra aktif; dan

Pengungkapan yang diperlukan sesuai PSAK 101: Penyajian Laporan Keuangan Syariah.

PSAKNo.106 paragraf14juga menyatakan bahwa "Investasi musyarakah diakui pada saat penyerahan kas atau aset nonkas untuk usaha musyarakah". Perlakuan akuntansi yang terjadi selama proses mengangsur adalah pembayaran sewa. Ketika nasabah membayar sewa atas rumah tersebut, maka pembayaran tersebut dialokasikan kepada (i) pendapatan bagi hasil, dimana pendapatan bagi hasil ini adalah bentuk dari margin yang diinginkan oleh bank atas berlangsungnya akad MMQ tersbut. Pengalokasian selanjutnya adalah (ii) pembelian porsi bank, dimana nasabah mengangsur pelunasan atas pembayaran yang ditangguhkan oleh bank untuk membeli rumah secara bersyirkah tersebut. Ketika akad MMQ berakhir, PSAK No 106 pada paragraph 33 telah mengatur, "Pada saat akad diakhiri, investasi musyarakah yang belum dikembalikan oleh mitra aktif diakui sebagai piutang". (Noven dan Aishanafi, 2013)

\section{Praktik Musyarakah Mutanaqisa di Indonesia}

Produk Musyarakah Mutanaqishah dapat diaplikasikan dalam bentuk pembiayaan yang bersifat produktif maupun konsumtif. Di Indonesia, jenis pembiayaan ini dapat diaplikasikan pada pembiayaan kendaraan (KKB), maupun pembiayaan properti atau rumah (KPR). Standar produk MMQ yang diuraikan dalam review ini masih terbatas pada pembiayaan MMQ untuk kepemilikan properti, khususnya rumah (KPR iB) dengan pertimbangan kebutuhan dan praktik di pasar industri perbankan syariah. (OJK, 2016)

Bank Syariah di Indonesia masih sedikit yang menawarkan produk dengan akad musyarakah mutanaqisa. Dari hasil peneusuran penulis melalui website dari 13 Bank Umum Syariah di Indonesia, ditemukan bahwa ada empat BUS yang menawarkan produk dengan akad musyarakah mutanaqisa, yakni Bank Muamalat, Maybank Syariah, Panin Bank Syariah dan Bank Mega Syariah. Keempat BUS tersebut menawarkan produk kepemilikan aset yakni kepemiikan rumah dan kendaraan. Dimana pada empat BUS tersebut, mereka juga menawarkan kepemilikan aset menggunakan akad murabahah. Sehingga nasabah bisa menenukan pilihan, akad mana yang akan mereka gunakan. BUS lainnya mash menggunakan hanya akad murabahah dalam produk kepemilikan rumah dan kendaraan.

Saat ini, terdapat banyak Bank Syariah di dunia yang juga mempraktikan Musyarakah mutanaqisa untuk pembelian property. Diantaranya Malaysia (RHB Islamic Bank, Maybank Islamic, Kuwait Finance House), Timur Tengah (Al-Yusr Islamic Banking Oman Arab Bank, Meethaq Islamic Banking Bank Muscat Oman, Standard Chartered Dubai, Kuwait Finance House, Al Rajhi Bank, dan lain-lain. Di negara lain secara global penerapan akad musyaraah mutanaqisa tidak 
Tabel 2. Aspek-aspek Fitur Musyarakah Mutanaqisa

\begin{tabular}{|c|c|c|}
\hline No & Aspek & Keterangan \\
\hline 1 & Akad Pembiayaan & Akad pembiayaan musyarakah mutanaqisa \\
\hline 2 & Tujuan Pembiayaan & $\begin{array}{l}\text { Pembelian property baru (ready stock), property lama (second) atau } \\
\text { property baru indent } \\
\text { Take over } \\
\text { Refinancing }\end{array}$ \\
\hline \multirow[t]{6}{*}{3} & Objek Pembiayaan (Jenis & Rumah Tinggal \\
\hline & Properti) & Rumah Susun (Rusun) \\
\hline & & Rumah Toko (Ruko) \\
\hline & & Rumah Kantor (Rukan) \\
\hline & & Apartemen \\
\hline & & Kondominium \\
\hline 4 & Jangka Waktu Pembiayaan & $\begin{array}{l}\text { Pembiayaan Jangka Menengah (Intermediate Term Financing) atau } \\
\text { Jangka Panjang (Long Term Financing) }\end{array}$ \\
\hline 5 & Kriteria Nasabah & Peorangan/Individu atau Badan Usaha \\
\hline 6 & Plafond Minimun & $\begin{array}{l}\text {... (sesuai kebijakan Bank dan peraturan perundang-undangan yang } \\
\text { berlaku) }\end{array}$ \\
\hline 7 & Palfond Maksimum & $\begin{array}{l}\text {... (sesuai kebijakan Bank dan peraturan perundang-undangan yang } \\
\text { berlaku) }\end{array}$ \\
\hline 8 & Sifat Fasilitas & Revolving atau Non-Revolving \\
\hline 9 & Mata Uang & Rupiah atau Valuta Asing \\
\hline 10 & Media Penarikan & Kas atau transfer atau RTGS atau Cek atau Bilyet Giro \\
\hline 11 & Nisbah Bagi Hasil & Bank: Nasabah (disepakati bersama) \\
\hline 12 & Biaya-biaya & $\begin{array}{l}\text { Biaya perolehan menjadi beban bersama, biaya selama masa sewa } \\
\text { menjadi beban penyewa sedangkan biaya peralihan kepemilikan } \\
\text { menjadi beban pembeli }\end{array}$ \\
\hline 13 & Hishshah (Porsi modal) & $\begin{array}{l}\text { Nilai per } 1 \text { unit hishshah disepakati di awal dan tidak berubah } \\
\text { nilainya selama masa pembiayaan }\end{array}$ \\
\hline 14 & Tarif Sewa & $\begin{array}{l}\text { Tarif sewa yang dikenakan kepada penyewa aset property tersebut } \\
\text { berdasarkan pada harga pasar atau menggunakan harga sewa yang } \\
\text { disepakati selama periode pricing yang berlaku }\end{array}$ \\
\hline
\end{tabular}

hanya terbatas pada kepemilikan rumah dan kendaraan saja, seperti yang saya tuliskan pada halaman sebelumnya pada bagian musyarakah mutanaqisa bahwa ada setidaknya tujuh jenis perwujudan akad musyarakah mtanaqisa. (Muhammad Iman, 2016)

Fatwa yang mengatur mengenai akad musyarakah mutanaqisa di Indonesia adalah fatwa DSN-MUI Nomor: 73/DSN-MUI/ XI/2008. Dalam fatwa tersebut dikatakan bahwa kepemilikan aset dapat dilakukan dengan cara menggunakan akad musyarakah mutanaqisa. Dalam akad musyarakah mutanaqisa, pihak pertama (syarik) wajib berjanji untuk menjual seluruh hishshah (porsi) nya secara bertahap dan pihak kedua (syarik) wajib membelinya. Setelah selesai pelunasan penjualan, seluruh hishshah LKS beralih kepada syarik lainnya (nasabah). Aset musyarakah mutanaqisa dapat di-ijarah-kan kepada syarik ata pihak lain.
Apabila aset musyarakah menjadi objekijarah, maka syarik (nasabah) dapat menyewa aset tersebut dengan nilai ujrah yang disepakati. Keuntungan yang diperoleh dari ujrah tersebut dibagi sesuai dengan nisbah yang telah disepkati dalam akad, sdangkan kerugian harus berdasarkan proporsi kepemilikan. Nisbah keuntungan dapat mengikuti perubahan proporsi kepemilikan sesuai kesepakatan para syarik.

Otoritas Jasa Keuangan menetapkan aspek-aspek yang termasuk dalam fitur musyarakah mutanaqisa, seperti pada tabel 2.

\section{KESIMPULAN}

Musyarakah mutanaqishah (diminishing partnership) adalah bentuk kerjasama antara dua pihak atau lebih untuk kepemilikan suatu barang atau asset. Dimana kerjasama ini akan 
mengurangi hak kepemilikan salah satu pihak sementara pihak yang lain bertambah hak kepemilikannya.

Akad ini menjadi inovasi baru bagi Bank Syariah di Indonesia dalam memenuhi kebutuhan masyarakat. Akad ini lebih baik jika dibandingkan dengan conventiona lease yang secara sepintas seolah tampak sama dengan akad musyarakah mutanaqisa.

Akad musyarakah mutanaqisa mengguakan PSAK 106 tentang musyrakah dalam perlakuan akuntansinya. Fatwa DSN-MUI Nomor: 73/DSN- MUI/XI/2008 tentang akad musyarakah mutanaqisa memperbolehkan akad ini berlangsung.

Di Indonesia, empat dari 13 Bank Umum Syariah menawarkan produk dengan akad musyarakah mutanaqisa, yakni pada pembiayaan kepemilikan rumah dan kendaraan. Selain di Indonesia, juga telah banyak bank syariah yang menerapkan akad ini.

\section{DAFTAR PUSTAKA}

Aris, Nooraslinda Abdul, dkk. (2012), “Islamic House Financing: Comparison between Bai Bithamin Ajil (BBA) and Musyarakah Mutanaqisah (MM)", African Journal of Business Management, Vol. 6 ,No. 1, pp. 269 Divisi Pengembangan Produk dan Edukasi Departemen Perbankan Syariah. (2016), Standar Produk Perbankan Syariah Musyarakah Mutanaqishah, Otoritas Jasa Keuangan, Jakarta
Fatwa DSN-MUI Nomor: 73/DSN-MUI/ XI/2008

Mengapa Bank Syariah harus Menerapkan Musyarakah Mutanaqisa? http://www. iqtishadconsulting.com/content/read/blog/ mengapa-bank-syariah-harus-menerapkanmusyarakah-mutanaqishah, diakses tanggal 7 Januari 2017

Mihajat, M. ImanSastra, (2016), “The comparison between Musharakah Mutanaqisah and Conventional Leasing Structures, Which One is Better?", Journal of Islamic Banking and Finance. Vol. 33 No. 1, pp. 65

Naim, Asmadi Mohamed. (2015), “The Practices of Musharakah Mutanaqisah in Iskamic Financial Institutions", International Journal of Education and Social Science, Vol. 2, No. 3, pp. $109-110$

Pernyataan Standar Akuntansi Keuangan No. 106 tentang Musyarakah (2007), Ikatan Akuntan Indonesia, Jakarta

Rohmi, Putri Kamilatur. (2015), “Implementasi Akad Musyarakah Mutanaqisah pada Pembiayaan Kepemilikan Rumah di Bank Muamalat Lumajang", Iqtishoduna, Vol. 5 No.1, pp. 20 dan 25

S. Khadifya, Aishanafi dan Noven Suprayogi. (2013), "Perlakuan Akuntansi Akad Musyarakah Mutanaqisah (Studi Kasus: KPR iB pada Bank Muamalat Cabang Darmo Surabaya)", Universitas Airlangga

Taqi Usmani (2002), An Introduction to Islamic Finance, Kluwer Law International 